\title{
Somatic embryogenesis in Carica papaya as affected by auxins and explants, and morphoanatomical-related aspects
}

\author{
JAMILE L.D. CIPRIANO ${ }^{1}$, ANA CLÁUDIA F. CRUZ ${ }^{2}$, KARINA C. MANCINI ${ }^{3}$, EDILSON R. \\ SCHMILDT ${ }^{3}$, JOSÉ CARLOS LOPES ${ }^{4}$, WAGNER C. OTONI ${ }^{2}$ and RODRIGO S. ALEXANDRE \\ ${ }^{1}$ Instituto Federal de Minas Gerais, Campus Sabará, Avenida Serra da Piedade, \\ 299, Morada da Serra, 34515-640 Sabará, MG, Brazil \\ ${ }^{2}$ Universidade Federal de Viçosa, Departamento de Biologia Vegetal, Avenida Peter \\ Henry Rolfs, s/n, Campus Universitário, 36570-900 Viçosa, MG, Brazil \\ ${ }^{3}$ Universidade Federal do Espírito Santo, Centro Universitário Norte do Espírito \\ Santo, Rodovia BR 101, Km 60, 29932-540 São Mateus, ES, Brazil \\ ${ }^{4}$ Universidade Federal do Espírito Santo, Departamento de Produção Vegetal, Alto \\ Universitário, s/n, Guararema, 29500-000 Alegre, ES, Brazil \\ ${ }^{5}$ Universidade Federal do Espírito Santo, Departamento de Ciências Florestais e da Madeira, Avenida \\ Governador Lindemberg, 360, Centro, 29550-000 Jerônimo Monteiro, ES, Brazil
}

Manuscript received on May 2, 2016; accepted for publication on July 12, 2016

\begin{abstract}
The aim of this study was to evaluate somatic embryogenesis in juvenile explants of the THB papaya cultivar. Apical shoots and cotyledonary leaves were inoculated in an induction medium composed of different concentrations of 2,4-D $(6,9,12,15$ and $18 \mu \mathrm{M})$ or 4-CPA $(19,22,25,28$ and $31 \mu \mathrm{M})$. The embryogenic calluses were transferred to a maturation medium for 30 days. Histological analysis were done during the induction and scanning electron microscopy after maturing. For both types of auxin, embryogenesis was achieved at higher frequencies with cotyledonary leaves incubated in induction medium than with apical shoots; except for callogenesis. The early-stage embryos (e.g., globular or heartshape) predominated. Among the auxins, best results were observed in cotyledonary leaves induced with 4-CPA $(25 \mu \mathrm{M})$. Histological analyses of the cotyledonary leaf-derived calluses confirmed that the somatic embryos (SEs) formed from parenchyma cells, predominantly differentiated via indirect and multicellular origin and infrequently via synchronized embryogenesis. The secondary embryogenesis was observed during induction and maturation phases in papaya THB cultivar. The combination of ABA $(0.5 \mu \mathrm{M})$ and $\mathrm{AC}\left(15 \mathrm{~g} \mathrm{~L}^{-1}\right)$ in maturation medium resulted in the highest somatic embryogenesis induction frequency $\left(70 \mathrm{SEs}\right.$ callus $\left.^{-1}\right)$ and the lowest percentage of early germination (4\%).
\end{abstract}

Key words: Carica papaya L., juvenile explants, maturation, microscopic analysis, synthetic auxins.

$\overline{\text { Correspondence to: Jamile Lenhaus Detoni Cipriano }}$

E-mail: miledetoni@gmail.com 


\section{INTRODUCTION}

The papaya (Carica papaya L.) is a very important fruit crop species worldwide. In Brazil, the state of Espírito Santo is one of the largest producers and exporters of papaya fruits. Several commercial genotypes of this species exist; for instance the THB cultivar, a selection within the 'Solo' group of fruits. This cultivar has been widely accepted among producers of northern Espírito Santo for its high productivity and small stature. In addition, the THB cultivar exhibits low gene segregation, which allows producers to use the seeds of the fruits harvested in the crop to produce new planting material.

Despite the economic importance of the THB cultivar, few studies in the literature have investigated its propagation. Commercially, papaya trees are propagated from seeds; however, seeds can be used for other purposes. For example, zygotic embryos (Ascencio-Cabral et al. 2008, Farzana et al. 2008, Malabadi et al. 2011, Anandan et al. 2012) or segments of seedlings (Yu et al. 2003, Saha et al. 2004, Farzana et al. 2008, Homhuan et al. 2008) can be used in tissue culture to produce explants and somatic embryos via somatic embryogenesis. This technique produces large numbers of somatic embryos that can be transformed into plantlets, identified as hermaphrodite ex vitro and subsequently rescued in vitro and used in the field.

Besides producing large numbers, somatic embryos are used to obtain transgenic papaya plants from Agrobacterium-mediated transformation. The development of this technique was successful using somatic embryos obtained from hypocotyl on solid medium (Fitch et al. 1993) or embryogenic cell suspension (Carlos-Hilario and Christopher 2015). The genotype may influence the variation of embryogenic responses during the induction and maturation phase in plant tissue (Bell et al. 1993). In addition, factors such as the type and concentration of auxin (Anandan et al. 2012), the type of explant (Capelo et al. 2011), presence or absence of abscisic acid (Bell et al. 1993), activated carbon (López-Pérez et al. 2005) or osmotic substances (Heringer et al. 2013) can alter the responses among genotypes.

In virtue of the scarcity of studies on THB cultivar and the significant interest of somatic embryogenesis applied to papaya, histological analyses are required to understand the induction and maturation stages of the somatic embryos. This present study aimed to evaluate the embryogenic induction of papaya THB cultivar from the explant type (apical shoot and cotyledonary leaf) and auxin (2,4-D and 4-CPA), establish the maturation medium favorable to the normal formation of the embryos, as well as analyzing the morphoanatomical aspects of its development.

\section{MATERIALS AND METHODS}

\section{PLANT MATERIAL}

After the sarcotesta removal with calcium hydroxide, seeds from ripe fruits of the papaya tree THB cultivar were disinfected in a laminar flow hood in $70 \%$ ethanol for one minute, in a commercial solution of sodium hypochlorite $(2.5 \%)$ with three drops of Tween $-20^{\circledR}$ for 15 minutes and in hydrogen peroxide $(50 \%)$ for 10 minutes. The seeds were then washed three times with autoclaved distilled water.

After disinfection, the seeds were inoculated in tubes containing $10 \mathrm{~mL}$ of MS medium (Murashige and Skoog 1962) with total concentrations of salts, myo-inositol $\left(100 \mathrm{mg} \mathrm{L}^{-1}\right)$, sucrose $\left(30 \mathrm{~g} \mathrm{~L}^{-1}\right)$ and $\operatorname{agar}\left(8 \mathrm{~g} \mathrm{~L}^{-1}\right)$; the $\mathrm{pH}$ of the medium was adjusted to $5.7 \pm 0.1$ before the addition of the gelling agent. The tubes were left in an incubator with a $12 \mathrm{~h}$ photoperiod and alternating (day and night) temperatures of $20-30^{\circ} \mathrm{C}$. After the primary radicle began to protrude, the tubes were placed in the dark under the same temperature regime. 


\section{INDUCTION OF SOMATIC EMBRYOGENESIS}

Firstly, both auxins (2,4-D and 4-CPA) were used at concentrations of $0,12.5,25,37.5$ and $50 \mu \mathrm{M}$ but the best results for the formation of embryogenic calluses with 2,4-D was $12.5 \mu \mathrm{M}$ and 4-CPA was 25 $\mu \mathrm{M}$ (data not shown). After that, it was decided to use different concentrations for auxins in an attempt to maximize the results of somatic embryogenesis in both inductors. Apical shoots (AS) and cotyledonary leaves (CL) obtained from 30-day-old seedlings grown in vitro were inoculated in $90 \times 15 \mathrm{~mm}$ polystyrene Petri plates (Global Trade Technology, Brazil) containing induction medium (IM) composed of MS medium with total concentrations of salts, myo-inositol (100 $\left.\mathrm{mg} \mathrm{L}^{-1}\right)$, sucrose (30 $\left.\mathrm{g} \mathrm{L}^{-1}\right)$ and Phytagel ${ }^{\circledR}\left(2.8 \mathrm{~g} \mathrm{~L}^{-1}\right)$ supplemented with either 2,4-dichlorophenoxyacetic acid (2,4$\mathrm{D}$, at concentrations of $6,9,12,15$ or $18 \mu \mathrm{M})$ or 4-chlorophenoxyacetic (4-CPA, at concentrations of $19,22,25,28$ or $31 \mu \mathrm{M})$. The $\mathrm{pH}$ of the IM was adjusted to $5.7 \pm 0.1$ before the addition of Phytagel $^{\circledR}$.

After the explants were inoculated, the Petri dishes were sealed with PVC plastic film (Goodyear, São Paulo, Brazil), wrapped with foil to prevent light entry and kept in an incubator at 27 $\pm 1{ }^{\circ} \mathrm{C}$ for 50 days. Callogenesis (\%) (sum between non-embryogenic and embryogenic calluses), embryogenic calluses (\%) and the number of somatic embryos per explant (globular, heartshaped, torpedo and cotyledonary) that developed were measured.

\section{MATURATION OF SOMATIC EMBRYOS}

After a 50-day incubation period in IM, the calluses underwent the cell potency assay, through the double-staining with acetocarmine $(2 \%)$ and Evan's blue (0.5\%) (Durzan and Gupta 1988). Thus, embryogenic callus was identified by the red color in the light microscope. The results of this assay and the relevant statistical analyses enabled the selection of the optimal concentrations of medium components. The embryogenic calluses were selected and transferred to a variety of maturation media (MM): IM without growth regulators (GR); IM + abscisic acid (ABA, $0.5 \mu \mathrm{M}$ ); $\mathrm{IM}+\mathrm{ABA}(0.5 \mu \mathrm{M})+$ activated charcoal $(\mathrm{AC}, 15 \mathrm{~g}$ $\left.\mathrm{L}^{-1}\right) ; \mathrm{IM}+\mathrm{ABA}(0.5 \mu \mathrm{M})+\mathrm{AC}\left(30 \mathrm{~g} \mathrm{~L}^{-1}\right) ;$ and IM $+\mathrm{ABA}(0.5 \mu \mathrm{M})+$ polyethylene glycol (PEG, $60 \mathrm{~g}$ $\left.\mathrm{L}^{-1}\right)$. The Petri dishes were kept in incubators with 12-hour photoperiod at $27 \pm 1^{\circ} \mathrm{C}$ for 30 days. The frequency of somatic embryo (SE) induction per callus and the percentage of germinated SEs were measured.

\section{LIGHT MICROSCOPY}

For the anatomical studies, cotyledonary leaves of Carica papaya L. submitted to treatment with 4-CPA $(25 \mu \mathrm{M})$ and grown in induction medium were collected on days 1, 2, 7, 14, 21, 28, 35 and 50; control cotyledonary leaves grown without auxins were also collected. All of the cotyledonary leaves were fixed in Karnovsky's solution (Karnovsky 1965). After fixation, the samples were dehydrated in an ethanol series and embedded in methacrylate (Historesin ${ }^{\circledR}$, Leica). Cross-sections and longitudinal sections ( $5 \mu \mathrm{M}$ thick) were obtained with an automatic rotary microtome (RM2155, Leica) equipped with a disposable glass knife and stained with toluidine blue at $\mathrm{pH} 4.0$ (O'Brien and McCully 1981) for 15 minutes. The slides were mounted in synthetic resin $\left(\right.$ Permount $\left.^{\circledR}\right)$. The analyses and photo-documentation were performed under a light microscope (Olympus-AX 70) coupled to a photomicrography system (Olympus U-Photo) in Viçosa, Minas Gerais $\left(20^{\circ} 45^{\prime} 33.8^{\prime \prime} \mathrm{S}\right.$ and $42^{\circ} 52^{\prime} 6.5^{\prime} \mathrm{W}$ ).

\section{SCANNING ELECTRON MICROSCOPY}

The post-maturated samples fixed in Karnovsky's solution were dehydrated in an ethanol series (culminating in 100\% alcohol), submitted to 
critical point drying with $\mathrm{CO}_{2}$ (Autosamdri 815, Tousimis $\left.^{\circledR}\right)$, placed in stubs and sputtered with a layer of gold (Desk V, Denton Vacuum ${ }^{\circledR}$ ). The analyses and photo-documentation were conducted using a scanning electron microscope (JSM $6610 \mathrm{LV}, \mathrm{Jeol}^{\circledR}$ ), and all images were digitally processed. The analyses were performed in Vitória, Espírito Santo (20¹7'53.1” S and 40¹8'57.9” W).

\section{STATISTICAL ANALYSIS}

The induction stage experiment consisted of a completely randomized design (CRD) in a $2 \times 5$ factorial arrangement with a total of 10 treatments. Two types of explants (AS and CL) and five concentrations of either 4-CPA $(19,22,25,28$ and $31 \mu \mathrm{M})$ or $2,4-\mathrm{D}(6,9,12,15$ and $18 \mu \mathrm{M})$ were used, with four replicates consisting of three dishes with five explants each. The maturation stage experiment also consisted of a CRD with five treatments and five replicates of three dishes containing five embryogenic calluses $\left(10 \mathrm{~mm}^{2}\right)$ each. Data were submitted to analysis of variance with the F-test; mean values were compared using the Tukey test at 5\%; and regression analyses were conducted using Genes software (Cruz 2016).

\section{RESULTS}

\section{INDUCTION OF SOMATIC EMBRYOGENESIS}

For both auxins, the type of explant influenced ( $p$ $<0.01)$ the formation of embryogenic calluses but not the formation of calluses (Tables I and II). In general, cotyledonary leaves formed more somatic embryos than the apical shoots. In media containing $2,4-\mathrm{D}, 62 \%$ of the cotyledonary leaves and only $10 \%$ of the apical shoots produced embryogenic calluses (Table I). The concentration of 2,4-D had no effect on the formation of SEs.

When 2,4-D was added to the medium, only the type of explant influenced $(p<0.01)$ the formation of somatic embryos (SE), the somatic embryos tended to be globular, heart-shaped, torpedo-like and similar to the cotyledonary embryos. In cotyledonary leaves cultured produced more globular somatic embryos (8.85 per explant), heart-shaped somatic embryos (5.50 per explant) and torpedo-like somatic embryos (3.35 per explant) than the AS explants $(0.45,0.10$ and 0.0 per explant, respectively) (Table I).

Despite no interaction between the factors (explants $\mathrm{x}$ concentrations) $(p>0.05)$, the 4-CPA concentration $(19,22,25,28$ and $31 \mu \mathrm{M})$ influenced $(p<0.01)$, as well as the type of explant, the results observed for the embryogenic calluses (Table IIA). The mean induction frequency of embryogenic calluses was higher for the cotyledonary leaves (78\%) than for the apical shoot explants (6.3\%, Table IIA).

The concentration of auxin had a significant effect on the formation of embryogenic calluses only for 4-CPA and for cotyledonary leaves despite the absence of an interaction between the means of the factors explants and concentrations. The regression analysis showed that these factors had

TABLE I

In vitro induction of apical shoot explants (AS) and cotyledonary leaves (CL) from the THB cultivar of Carica papaya $\mathrm{L}$. to calluses, embryogenic calluses and number of somatic embryos (SE) at various stages of development after a 50-day culture in MS medium supplemented with 2,4-D.

\begin{tabular}{ccccccc}
\hline \multirow{2}{*}{ Explants } & \multirow{2}{*}{ Callogenesis (\%) } & \multirow{2}{*}{$\begin{array}{c}\text { Embryogenic } \\
\text { Calluses (\%) }\end{array}$} & Globular & Heart-shape & Torpedo & Cotyledonary \\
\cline { 4 - 7 } & & $10 \mathrm{~b}$ & $0.45 \mathrm{~b}$ & $0.10 \mathrm{~b}$ & $0.00 \mathrm{~b}$ & $0.00 \mathrm{a}$ \\
$\mathrm{AS}$ & $98 \mathrm{a}^{*}$ & $62 \mathrm{a}$ & $8.85 \mathrm{a}$ & $5.50 \mathrm{a}$ & $3.35 \mathrm{a}$ & $1.25 \mathrm{a}$ \\
\hline LSD & 1.85 & 4.27 & 2.61 & 1.78 & 1.27 & 1.30 \\
\hline
\end{tabular}

LSD: Lower Standard Deviation. * Means followed by the same letter in a column are not significantly different at the $5 \%$ probability level by Tukey's test. 
TABLE II

A - In vitro induction of THB cultivar of Carica papaya $\mathrm{L}$. apical shoot (AS) explants and cotyledonary leaves (CL) to calluses and embryogenic calluses in MS medium supplemented with 4-CPA. B - Mean number of somatic embryos (SE) formed at various stages of development cultured in the induction medium supplemented with different 4-CPA (19, 22, 25, 28 and $31 \mu \mathrm{M})$ for 50 days.

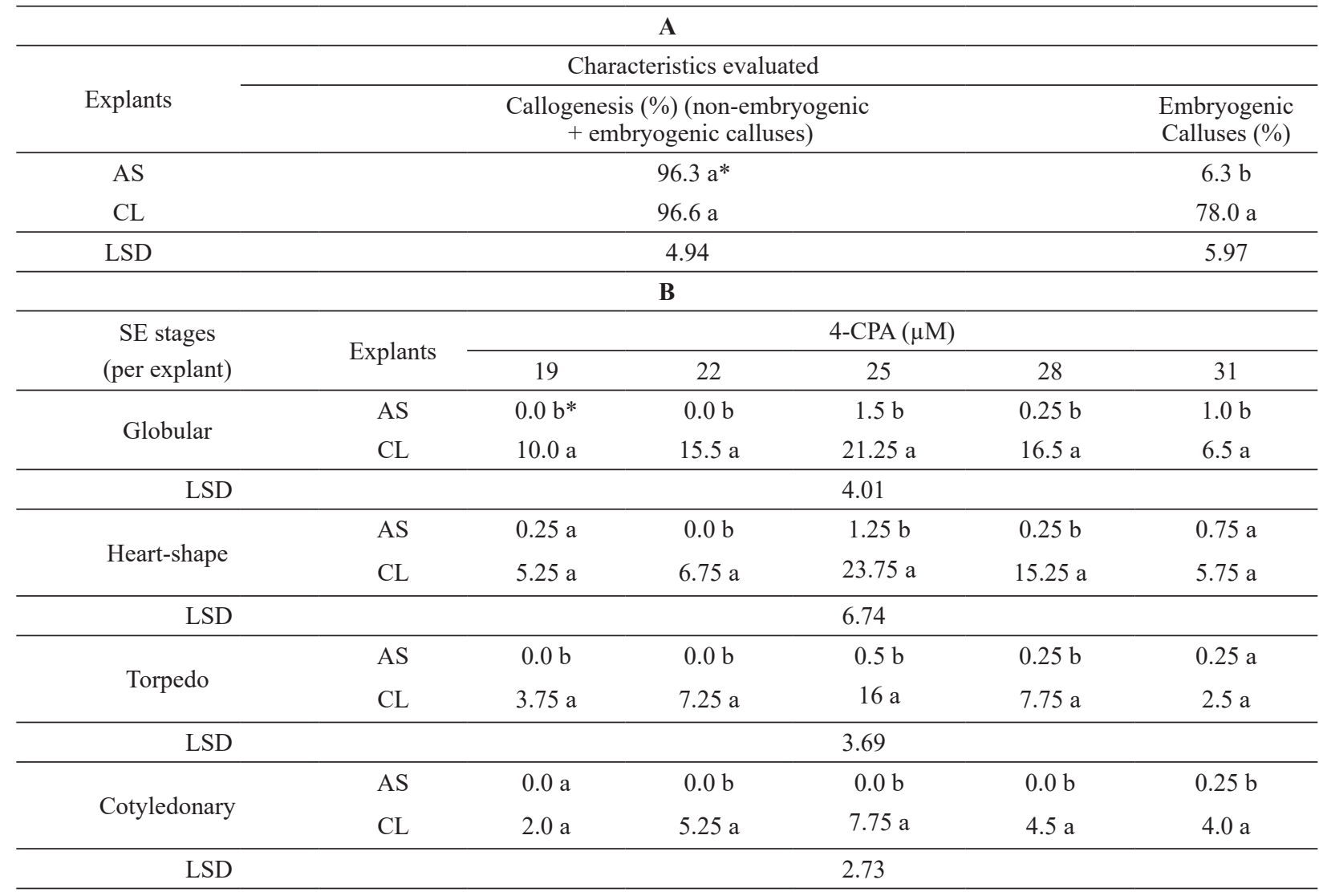

Exp: Explant; LSD: Lower Standard Deviation. ${ }^{*}$ Means followed by the same letter in a column are not significantly different at the $5 \%$ probability level by Tukey's test.

a quadratic effect on the induction frequency for both types of explants, and the highest induction frequency (48\%) was achieved with the $25.84 \mu \mathrm{M}$ concentration (Figure 1a).

As was the case with the cultures supplemented with 2,4-D, SEs in early development stages (i.e., globular and heart-shaped) predominated when the medium was supplemented with 4-CPA. For the different types of SE, almost all concentrations of 4-CPA, the means of CL were higher than AS: the greatest differences between the means of the explants were observed within the concentrations of $22 \mu \mathrm{M}$ (globular - 15.5 and 0.0 per explant; heart-shape -6.75 and 0.0 explant per; torpedo -
25.7 and 0.0 per explant; cotyledonary -5.25 and 0.0 per explant), $25 \mu \mathrm{M}$ (globular -21.25 and 1.5 explant per, heart-shape - 23.75 and 1.25 explant per; torpedo - 16 and 0.5 per explant; cotyledonary - 7.75 and 0.0 per explant) and $28 \mu \mathrm{M}$ (globular - 16.5 and 0.25 per explant; heart-shape - 15.25 and 0.25 explant per; torpedo -7.75 and 0.25 per explant; cotyledonary -4.5 and 0.0 per explant) (Table IIB).

For all embryogenic stages (globular, heartshaped and torpedo-like) in which a significant interaction between the type of explants and the concentration of 4-CPA was observed ( $p<0.01$ ), the quadratic model developed in the regression 

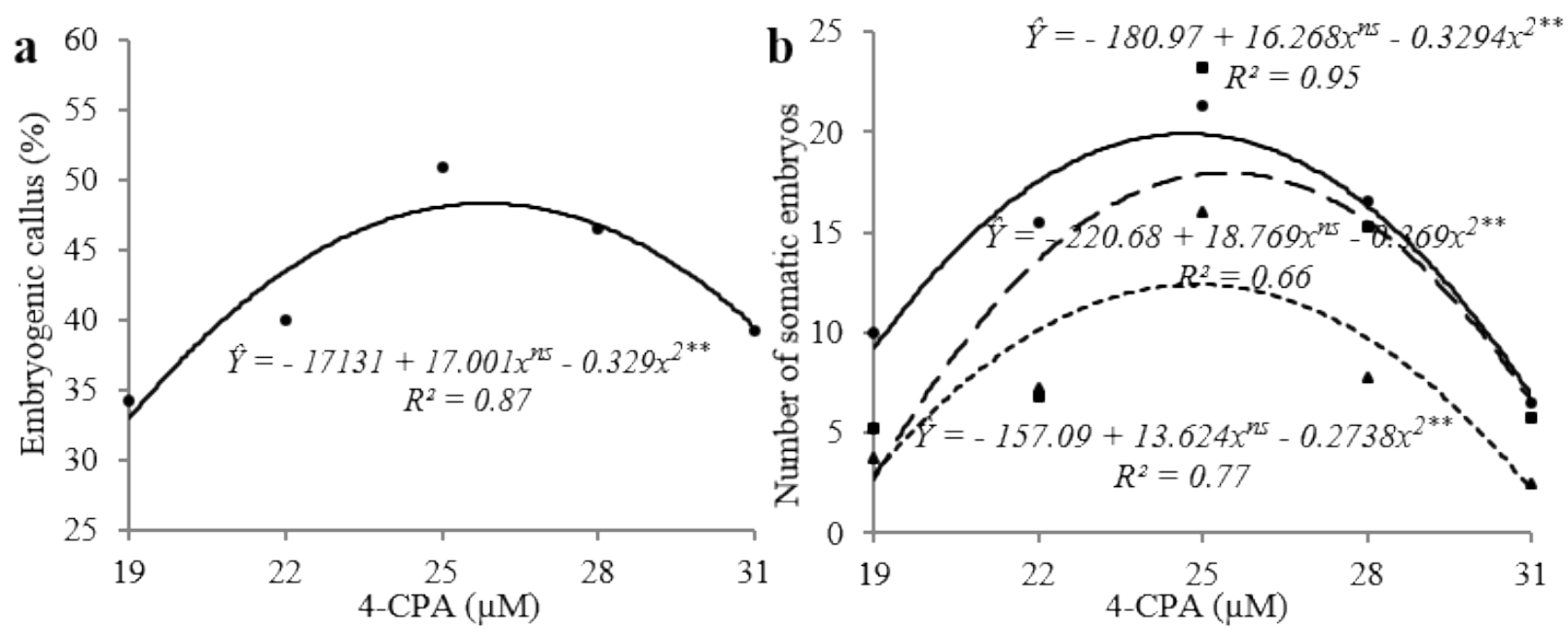

Figure 1 - (a) Percentage of embryogenic calluses obtained with THB cultivar of Carica papaya L. apical shoots and cotyledonary leaves incubated in induction medium containing different concentrations of 4-CPA (19, 22, 25, 28 and $31 \mu \mathrm{M})$ for 50 days. (b) Mean number of globular (continuous line), heart-shaped (dashed line) and torpedo-like (dotted line) somatic embryos (SE) produced from cotyledonary leaves cultured in induction medium containing 4-CPA for 50 days. ${ }^{* *}$ Significant at the $1 \%$ probability

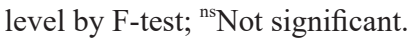

analysis was only able to explain the results obtained with treatments using cotyledonary leaves (Figure 1b). Likewise for other features, the maximum induction frequency of embryogenic calluses was achieved with 4-CPA at a concentration close to $25 \mu \mathrm{M}$ : globular $(24.72 \mu \mathrm{M})$, heart-shaped $(25.43$ $\mu \mathrm{M})$ and torpedo-like SEs $(24.86 \mu \mathrm{M})$.

Variations in the structure of the calluses induced from both types of explants were observed. Apical shoots produced small, solid, non-friable, light beige spongy calluses (Figure 2a). The cotyledonary leaves produced compact, shiny, cream or white calluses with friable regions (Figure $2 b)$. The cell potency assay was used to identify and select embryogenic mass regions (Figure 2c). In the light microscope, embryogenic cells were identified by the red color and non-embryogenic cells by the blue color.

For both auxin types, SEs in all stages of development were observed (Tables I and IIB, Figure 2); however, the microscopic analyses revealed a lack of synchronicity in the embryogenic process (Figure 2d-k).

\section{MATURATION OF SOMATIC EMBRYOS}

In the maturation stage, samples of embryogenic calluses obtained from the induction with 4-CPA $(25 \mu \mathrm{M})$ were selected. After 30 days, the composition of the maturation medium was found to influence the mean induction frequency of SEs and the percentage of germinated SEs (Table III).

The medium containing $\mathrm{ABA}(0.5 \mu \mathrm{M})$ and $\mathrm{AC}\left(15 \mathrm{~g} \mathrm{~L}^{-1}\right)$ proved to efficiently induce SE maturation; indeed, this medium produced significantly the highest mean number of SEs (70.5 SE callus $\left.{ }^{-1}\right)$. MS media without growth regulators (GR) were associated with much lower SE induction frequencies: produced 45.7 SE callus $^{-1}$; the medium containing $\mathrm{ABA}(0.5 \mu \mathrm{M})$ and PEG (60 $\left.\mathrm{g} \mathrm{L}^{-1}\right)$ produced 48.5 SE callus ${ }^{-1}$; and the medium containing ABA $(0.5 \mu \mathrm{M})$ produced 51.6 SE callus ${ }^{-1}$. The medium containing ABA $(0.5 \mu \mathrm{M})$ and $\mathrm{AC}\left(30 \mathrm{~g} \mathrm{~L}^{-1}\right)$ produced statistically more (54.2 SE callus ${ }^{-1}$ ) than the MS medium without GR, but amounts similar to the medium with $\mathrm{ABA}(0.5 \mu \mathrm{M})$ and PEG $\left(60 \mathrm{~g} \mathrm{~L}^{-1}\right)$ and the medium with $\mathrm{ABA}(0.5$ $\mu \mathrm{M})$ (Table III). 


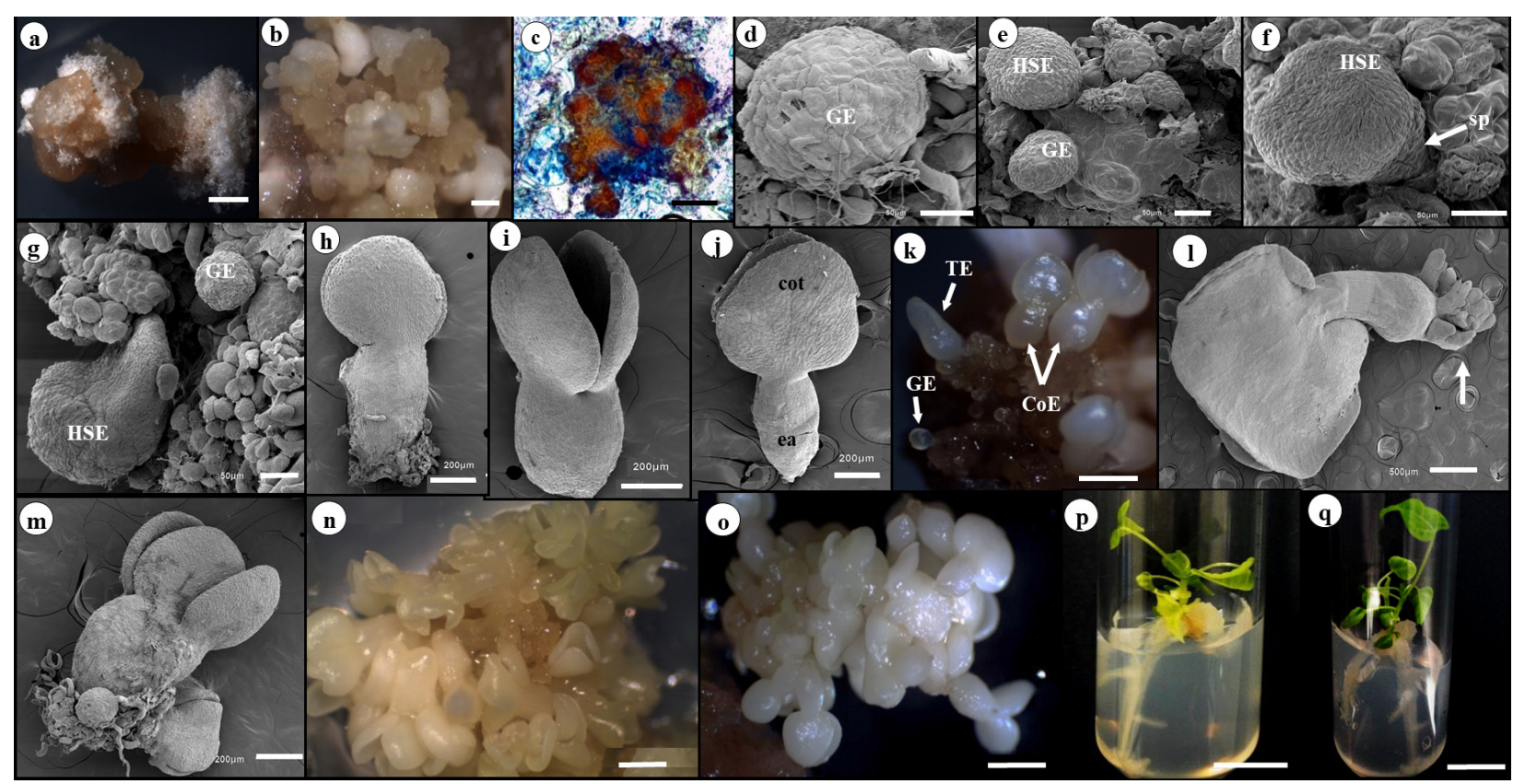

Figure 2 - Somatic embryogenesis in explants of Carica papaya L. THB cultivar. (a) Non-embryogenic callus formed from an apical shoot and (b) embryogenic callus formed from a cotyledonary leaf induced with 4-CPA (25 $\mu \mathrm{M})$. (c) Double staining assay in the callus induced with 4-CPA $(25 \mu \mathrm{M})$. (d, e, f, g) Ultrastructural analysis of somatic embryos (SE) in various stages of development following maturation. (h) Late torpedo-like embryos. (i) Early cotyledon and (j) normal late cotyledon embryo. (k) SE at different developmental stages, formation of asynchronized embryos. (l, m) Secondary embryogenesis (arrow) in maturation medium. SEs in maturation media: (n) ABA $(0.5 \mu \mathrm{M})+\mathrm{AC}\left(15 \mathrm{~g} \mathrm{~L}^{-1}\right) ;(\mathbf{o}) \mathrm{ABA}(0.5 \mu \mathrm{M})+\mathrm{PEG}\left(60 \mathrm{~g} \mathrm{~L}^{-1}\right)$. Normal converted plantlet originating from somatic embryogenesis: (p) ABA $(0.5 \mu \mathrm{M})+\mathrm{AC}\left(15 \mathrm{~g} \mathrm{~L}^{-1}\right)$; (q) $\mathrm{ABA}(0.5 \mu \mathrm{M})+\mathrm{PEG}\left(60 \mathrm{~g} \mathrm{~L}{ }^{-1}\right)$. Abbreviations: cot. cotyledons; ea. embryonic axis; CoE. cotyledonary somatic embryo; HSE. heart-shaped somatic embryo; GE. globular somatic embryo; TE. torpedo-shape somatic embryo; sp. suspensor. Bar = $2.0 \mathrm{~mm}(\mathbf{a}, \mathbf{b}, \mathbf{n}) ; 10 \mu \mathrm{m}(\mathbf{c}) ; 50 \mu \mathrm{m}(\mathbf{d}, \mathbf{e}, \mathbf{f}, \mathbf{g})$; $200 \mu \mathrm{m}(\mathbf{h}, \mathbf{i}, \mathbf{j}, \mathbf{m}) ; 0.5 \mathrm{~mm}(\mathbf{k}) ; 500 \mu \mathrm{m}(\mathbf{l}) ; 1.0 \mathrm{~mm}(\mathbf{o}) ; 10.0 \mathrm{~mm}(\mathbf{p}, \mathbf{q})$.

The most efficient maturation, low percentage of SEs that germinated precociously (4\% of germinating SEs), was achieved with the means containing $\mathrm{ABA}(0.5 \mu \mathrm{M})$ and $\mathrm{AC}\left(15 \mathrm{~g} \mathrm{~L}^{-1}\right)$ and ABA $(0.5 \mu \mathrm{M})$ and PEG $\left(60 \mathrm{~g} \mathrm{~L}^{-1}\right)$. The medium resulting in the highest percentage of germinated SEs (18\%) was the MS medium lacking GR; the medium containing ABA $(0.5 \mu \mathrm{M})$ and $\mathrm{AC}(30 \mathrm{~g}$ $\left.\mathrm{L}^{-1}\right)$ and the medium containing $\mathrm{ABA}(0.5 \mu \mathrm{M})$ resulted in precocious germination frequencies of $16 \%$ and $7 \%$, respectively (Table III).

Embryos of the THB papaya cultivar that were matured in medium containing $\mathrm{ABA}(0.5 \mu \mathrm{M})$ and $\mathrm{AC}\left(15 \mathrm{~g} \mathrm{~L}^{-1}\right)$ (Figure $\left.2 \mathrm{n}\right)$ or ABA $(0.5 \mu \mathrm{M})$ and PEG $\left(60 \mathrm{~g} \mathrm{~L}^{-1}\right)$ (Figure 2o), they were placed in medium without GR for the development of shoots and roots (Figure $2 \mathrm{p}-\mathrm{q}$ ) and were converted into normal seedlings most frequently (data no shown), although it has not been evaluated acclimatization.

\section{HISTOLOGICAL AND STRUCTURAL ANALYSIS}

The light microscopy (LM) and scanning electron microscopy (SEM) analyses were performed on cotyledonary leaves treated with 4-CPA $(25 \mu \mathrm{M})$ during the induction and post-maturation periods; these analyses were performed to follow the embryogenic process and analyze the morphology of the formed embryos (Figures 2 and 3).

The cotyledonary leaves of the THB papaya cultivar (Figure 3a) possess a single epidermal layer with juxtaposed rectangular cells; stomata are observed on both the abaxial and adaxial sides. In 
TABLE III

Maturation of somatic embryos (late torpedo and cotyledonary) of the THB cultivar of Carica papaya $L$. obtained from cotyledonary leaves cultured in induction medium supplemented with 4-CPA $(25 \mu \mathrm{M})$ in relation to the frequency of somatic embryo induction and the frequency of precocious germination of somatic embryos (SE) after 30 days of culture.

\begin{tabular}{|c|c|c|}
\hline Maturation media & $\begin{array}{l}\text { Frequency } \\
\left(\mathrm{SE} \text { callus }^{-1}\right)\end{array}$ & $\begin{array}{c}\text { Germinated } \\
\text { SE (\%) }\end{array}$ \\
\hline MS without GR & $45.7 \mathrm{c}^{*}$ & $18 \mathrm{a}$ \\
\hline $\mathrm{ABA}(0.5 \mu \mathrm{M})$ & $51.6 \mathrm{bc}$ & $7 \mathrm{c}$ \\
\hline $\mathrm{ABA}(0.5 \mu \mathrm{M})+\mathrm{AC}\left(15 \mathrm{~g} \mathrm{~L}^{-1}\right)$ & $70.5 \mathrm{a}$ & $4 \mathrm{~d}$ \\
\hline $\mathrm{ABA}(0.5 \mu \mathrm{M})+\mathrm{AC}\left(30 \mathrm{~g} \mathrm{~L}^{-1}\right)$ & $54.2 \mathrm{~b}$ & $16 \mathrm{~b}$ \\
\hline $\operatorname{ABA}(0.5 \mu \mathrm{M})+\operatorname{PEG}\left(60 \mathrm{~g} \mathrm{~L}^{-1}\right)$ & $48.5 \mathrm{bc}$ & $4 \mathrm{~d}$ \\
\hline LSD & 6.28 & 1.47 \\
\hline
\end{tabular}

ABA: abscisic acid; AC: activated charcoal; MS: Murashige and Skoog medium; PEG: polyethylene glycol; GR: growth regulator; LSD: lower standard deviation. *Means followed by the same letter in the column are not significantly different at the $5 \%$ probability level by Tukey's test.

the absence of induction, no dividing cells were observed. Pre-embryogenic cells were visualized after seven days of culture (Figure $3 b$ ); these cells were characterized by a small diameter, dense cytoplasm, large nuclei and evident nucleoli. These cells were internally formed from parenchymal cells. In addition to these cells, other dividing cells began to form visibly disorganized tissue, most likely the callus. No histological evidence of direct embryogenesis was observed. The intense meristematic activity observed after 14 days (Figure $3 \mathrm{c}$ ) and after 21 days (Figure 3d), disorganized the structure of the cotyledonary explants.

After approximately 28 days, the structure of the explants had become highly modified and the cotyledonary epidermis was completely disjointed (Figure 3e). The meristematic activity in the cells directed the callogenic mass to the periphery of the cotyledon, resulting in the extrusion of the embryogenic mass to the surface. When the embryogenic masses became exposed, several preembryogenic globular structures (independent or in the process of becoming independent) formed from epidermal and subepidermal cells of the callus (Figure 3f); these structures could be visualized within approximately 35 days. The formation of a callogenic structure suggests that embryogenesis occurred indirectly.

The formation of these globular structures from the initial explants represents the first stage of differentiation on the indirect pathway. After 35 days, somatic embryos in the globular stage, lacking a vascular connection to the parental tissue, were observed (Figure 3f).

The pre-globular embryos also further developed into torpedo-like embryos (Figure 3g) and cotyledons (Figure $3 \mathrm{~h}$ ) after 50 days. It is possible to observe the presence of protoderm and procambium layers in somatic embryos (Figure $3 \mathrm{~g}-\mathrm{h}$ ), similar to the layers observed in zygotic embryos.

During the induction stage (Figure $3 \mathrm{~g}$ ) and following the maturation stage (Figure 2d-k), globular embryos and embryos in late stages of development were visualized. Thus, the microscopic analyses confirmed that somatic embryogenesis in the THB papaya cultivar was not synchronized.

In the current study, a 50-day incubation period in the induction medium produced embryos in different stages of development within the same treatment (Tables I and IIB, Figure 1b) or callus (Figures 2k, 3g).

Secondary embryogenesis was observed during the induction (Figure $3 \mathrm{~g}$ ), but occurred more frequently in the explants cultured in maturation medium without auxins (Figure 21-m); these secondary embryos developed mainly from the surface of the embryonic axis near the root meristem of the primary embryos. 


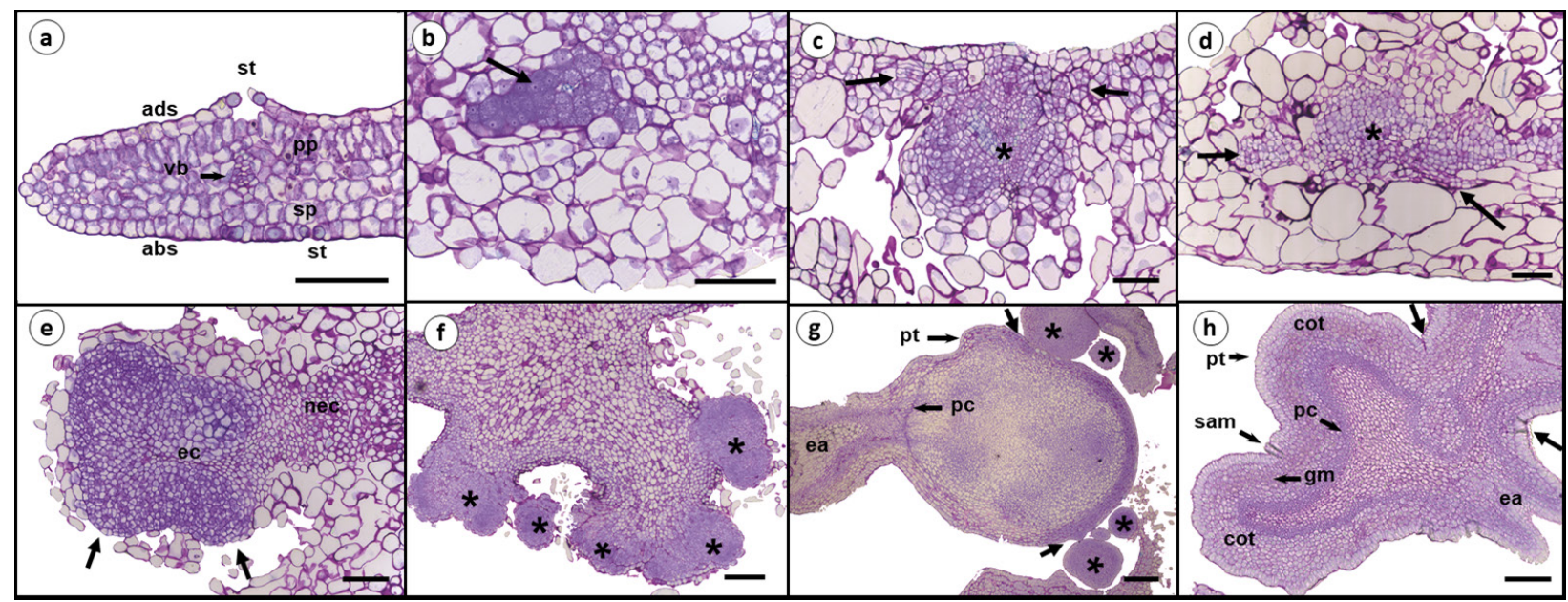

Figure 3 - Sequence of anatomical events occurring during the genesis of somatic embryos produced from cotyledonary leaves of the THB cultivar of Carica papaya L. cultured in induction medium with 4-CPA $(25 \mu \mathrm{M})$, and stained with toluidine blue. (a) Non-induced cotyledonary leaves at 30 days. (b) Pro-embryogenic mass at seven days. Cells with large nuclei and evident nucleoli (arrow). (c) Developing callugenic mass and embryogenic mass (*) at 14 days and (d) 21 days. Cells undergoing division (arrow). (e) Embryogenic callus exposed on the surface of explants breaking through the epidermis (arrow) after 28 days of culture in IM. (f) Several globular embryogenic structures formed indirectly at 35 days. (g) Somatic embryo in torpedo-like stage and globular embryos $\left(^{*}\right)$ at 50 days. Secondary embryogenesis, shown by the connection between embryos (arrow). (h) Cotyledonary embryo formed after 50 days of culture in IM showing the detachment regions (arrows) from the original tissue. Abbreviations: ec. embryogenic callus; nec. non-embryogenic callus; ea. embryonic axis; st. stomata; ads. adaxial side; abs. abaxial side; vb. vascular bundles; cot. cotyledons; sam. shoot apical meristem; gm. ground meristem. pc. procambium; sp. spongy parenchyma; pp. palisade parenchyma; pt. protoderm. Bar $=100 \mu \mathrm{m}(\mathbf{a}, \mathbf{b}, \mathbf{c}, \mathbf{d}, \mathbf{e}, \mathbf{h}) ; 200 \mu \mathrm{m}(\mathbf{g}, \mathbf{h})$.

\section{DISCUSSION}

\section{INDUCTION OF SOMATIC EMBRYOGENESIS}

Auxins are important for both the acquisition of embryogenic competence and for embryo development. Several studies in the literature have described the use of the auxin 2,4-D to induce embryogenesis in papaya explants (Castillo et al. 1998, Fernando et al. 2001, Renukdas et al. 2003, Yu et al. 2003, Ascencio-Cabral et al. 2008, Malabadi et al. 2011). The capacity of 2,4-D to activate embryogenic routes may be related to its ability to induce stress genes that contribute to the cellular reprogramming of somatic to embryogenic cells (Fehér 2005, 2015). Conversely, no studies have described the use of the auxin 4-CPA to induce embryogenesis in the papaya. However, 4-CPA has been successfully used in other species such as Pisum sativum (Loiseau et al. 1995), Rosa sp.
(Kintzios et al. 1999) and Psidium guajava (Moura and Motoike 2009).

The induction of zygotic embryos of the Co-7 cultivar of papaya with $2,4-\mathrm{D}(9.05 \mu \mathrm{M})$ resulted in a callus induction frequency of $87.11 \%$ and an embryogenic callus induction frequency of 75.12\% (Anandan et al. 2012). A 46.7\% somatic embryogenesis rate was reported when immature embryos of the papaya hybrid UENF/Caliman 01 were cultured on MS-based induction medium with $20 \mu \mathrm{M}$ 2,4-D. High somatic embryogenesis frequencies $(90.5 \%)$ were achieved when cotyledonary explants from Cassia angustifolia Vahl were cultured on MS medium with $10 \mu \mathrm{M}$ 2,4-D combined with $1.0 \mu \mathrm{M}$ benzyladenine (BA); a production of 22.8 embryos/explant was verified, of which $35.3 \%$ germinated in the same medium after six weeks in culture (Parveen and Shahzad 2014). 
Auxins are involved in regulating the cell cycle and promoting cell differentiation and play important roles in somatic embryogenesis in several species (Jiménez 2005, Kurczynska et al. 2007, Capelo et al. 2011, Rocha et al. 2012).

Different inducers may produce different embryogenic responses in the same genotype. 4-CPA and 2,4-D are synthetic auxins with herbicidal activities that belong to the chlorophenoxyacetic group; they differ only by a chlorine atom at carbon 2 of the phenoxy ring. The interactions that take place between auxin herbicides and plant tissue are not fully understood; however, it is clear that the biological responses to these two auxins are distinct.

The response (and therefore the sensitivity) of cells to a growth regulator is related to the number of receptors present on the cell surface and differs for different types of tissue (Loschiavo et al. 1991). The cells that are sensitive to the inducers possess receptors that bind to the hormone and subsequently initiate the response that renders the cells competent for embryogenesis.

In a study investigating the embryogenic response of rye plants incubated in different modified forms of phenoxy acid or in a control solution of 2,4-D, small changes in the size of the straight carbon chain or even in the structure of the phenoxy ring caused enormous variations in the frequency of embryogenic induction (Stuart and Mccall 1992). This analysis highlights the specificity of the membrane receptors and the resulting varying affinity for the different molecules. In the current study, the response of cells varied with the different auxins: indeed, the embryogenic callus response and the types of somatic embryos that developed varied significantly with different concentrations of 4-CPA but not with different concentrations of 2,4-D.

The presence of a specific protein receptor for 2,4-D has not yet been reported (Chinalia et al. 2007); it is likely that the coupling and recognition of 2,4-D occurs via specific receptors for endogenous auxins such as indole-3-acetic acid (IAA) (Loschiavo et al. 1991, Sugaya et al. 2000, Walsh et al. 2006).

The explant choice is also a very important issue, as characteristics such as the level and preservation of juvenility, the presence of meristems and the oxidative metabolism, physiological status and genetic stability of the organism vary with different types of explants (Prakash and Gurumurthi 2009).

In the current study, regardless of the type of auxin, differences in the induction frequency of embryogenic calluses and somatic embryos were observed for different types of explants.

These observed differences may support the hypothesis that somatic embryogenesis occurs in response to plant tissue senescence (Bell et al. 1993). Thus, it is possible to understand that the apical shoots containing the shoot apical meristem constitute a physiologically young region, the embryogenic process may be inhibited or delayed. However, when the cotyledonary leaves are removed from the seedling, senescence begins, signaling the onset of the development of somatic embryos.

Auxin herbicides cause chemical stress in the plant (Zavattieri et al. 2010) and can initiate a cascade of molecular and biochemical signaling processes that activate genes involved in senescence such as 1-aminocyclopropane-1carboxylic acid (ACC) synthase, which produces ethylene, and 9-cis-epoxycarotenoid dioxygenase (NCED), which synthesizes ABA, both of which are important for embryo maturation (Grossmann 2003, 2007, Raghavan et al. 2005, 2006).

\section{MATURATION OF SOMATIC EMBRYOS}

The maturation medium containing ABA (0.5 $\mu \mathrm{M})$ and $\mathrm{AC}\left(15 \mathrm{~g} \mathrm{~L}^{-1}\right)$ satisfactorily promoted the development of somatic embryos. The activated 
charcoal (AC) in the maturation medium can adsorb inhibitory substances such as phenolic compounds, ethylene or auxin residues that could prevent the development of somatic embryos (Pereira et al. 2008, Aboshama 2011). In a study investigating the maturation of somatic embryos of different varieties of grape, López-Pérez et al. (2005) found that the use of a medium supplemented with AC $\left(2.5 \mathrm{~g} \mathrm{~L}^{-1}\right)$ produced a significantly higher maturation rate (99.5\%) than the medium without AC (5.8\%).

In THB papaya cultivar, the concentration of 15 $\mathrm{g} \mathrm{L}^{-1} \mathrm{AC}$ combined with ABA adsorbed inhibitory substances and allowed the continuous and adequate release of this hormone to the embryogenic tissue, thus favoring its development. However, it is not observed when the AC concentration was increased to $30 \mathrm{~g} \mathrm{~L}^{-1}$. It is likely that very high AC concentrations can adsorb substances that are essential for the development of somatic embryos, such as ABA.

Despite the low induction frequency of SEs (48.5 SE callus ${ }^{-1}$ ), the medium containing ABA $(0.5 \mu \mathrm{M})$ and PEG $\left(60 \mathrm{~g} \mathrm{~L}^{-1}\right)$ very efficiently inhibited precocious germination (4\%). Studies have described the ability of PEG to increase the osmolarity of the medium and increase the frequency of somatic embryo induction (Castillón and Kamo 2002, Vooková and Kormuták 2002, Steiner et al. 2005, Alkhateeb 2006, Calic-Dragosavac et al. 2010, Vale et al. 2014). The results achieved with PEG may be related to the non-plasmolyzing osmotic effect of this compound: PEG may be able to induce water stress even if no water actually enters the plant cell (Alkhateeb 2006), and lead to an increased protein synthesis (Heringer et al. 2013, Vale et al. 2014).

ABA has been widely used in maturation medium because it can induce the final development of the embryo through the accumulation of LEA proteins (late embryogenesis abundant), related to the maintenance of desiccation tolerance (Dodeman et al. 1997, Capelle et al. 2010), stimulate the storage of reserve substances (Gutmann et al. 1996, Sholi et al. 2009) and prevent precocious germination (von Arnold et al. 2002). The process that drives the formation of secondary embryos is not clearly understood; however it can be associated with the time spent in the induction medium or maturation medium. In current study secondary embryos were identified in maturation medium. Some studies have correlated the formation of secondary somatic embryos depending on the concentration of exogenous ABA (Iida et al. 1992, Ogata et al. 2005, Aman and Afrasiab 2014) or the types of somatic embryos placed in MM with ABA (Lee et al. 1998, Calic et al. 2012).

Maturation media lacking this phytohormone were less able to inhibit the precocious germination of the THB papaya cultivar and more frequently produced abnormal embryos (data not shown). ABA (even at low concentrations) has been shown to be essential for the normal development and maturation of papaya (Renukdas et al. 2006).

The maturation phase, which is relatively short (30 days) for the THB papaya cultivar, was sufficiently long to enable the development of the cotyledonary somatic embryos and produce large numbers of normal seedlings (data not shown). Although the current study did not evaluate the rooting process of somatic embryos for ex vitro acclimatization, this point is one of the biggest challenges in papaya tissue culture. Recently, Pérez et al. (2016) reported high rooting efficiency (100\%) of papaya shoots using semi-solid medium with IBA and phloroglucinol. According to the authors, this combination favored the in vitro rooting and increased plants survival in ex vitro acclimatization. The rooting process presents greater success in experiments using papaya cuttings, developing flowers and fruits early when compared to plants from seeds (Schmildt et al. 2016). 


\section{HISTOLOGICAL AND STRUCTURAL ANALYSIS}

The microscopic analysis of the developing somatic embryos revealed that the THB papaya cultivar and other varieties of papaya underwent similar and different embryogenic processes. In the current study, the pro-embryogenic masses were visualized after seven days of culture in induction medium; these masses were formed from parenchyma cells with no visible indication of direct embryogenesis. Fernando et al. (2001) described the direct formation of somatic papaya embryos of the Sunrise Solo cultivar from single protodermal cells after 18 days of culture in induction medium containing 2,4-D (9.05 $\mu \mathrm{M})$.

The structural disorganization of the tissue observed in cotyledonary explants following 14 days of culture is characteristic of the indirect embryogenesis process, which involves the formation of somatic embryos from callogenic masses (Pinto et al. 2011). However, two distinct groups of cells were observed: one was formed of large, non-embryonic cells at the periphery of the explants; the other group was localized more centrally and composed of small cells with a meristematic appearance. The same structural pattern was observed by Konieczny et al. (2012) during the somatic embryogenesis of Trifolium nigrescens Viv.

The double-staining assay is frequently used to detect embryogenic competence during the induction stage. The embryogenic cells are isodiametrical, dense cytoplasm and extremely reactive to acetocarmine, resulting in red staining (Durzan and Gupta 1988). This assay confirmed the presence of two distinct types of THB papaya cells following the induction stage. The acetocarminereactivity is linked to the competence of cells for somatic embryogenesis development (Steiner et al. 2005) and its chromosomal integrity (Munhoz et al. 2008). Moreover, the elongated cells are usually vacuolated, first sign of cell death, followed by the rupture of the membrane (Filonova et al. 2000), making cells permeable to Evan's blue. The carmine-acetic acid stain has also been successfully used to differentiate embryogenic and nonembryogenic cell populations in Passiflora (Silva et al. 2009, Pinto et al. 2011).

In addition to their indirect origin, somatic embryos of the THB papaya cultivar have a multicellular origin; more specifically, cells simultaneously dedifferentiate into different tissues that can subsequently form a single embryogenic mass (Rocha et al. 2012). In particular, embryogenic masses originating from the fusion of parenchymatic and epidermic cells can form embryogenic globular structures.

Somatic embryos of the THB papaya cultivar appear to have similar origins as other varieties of papaya (i.e., indirect and multicellular embryogenesis) (Fernando et al. 2001, AscencioCabral et al. 2008, Anandan et al. 2012).

The type and concentration of auxin and the sensitivity of the explant cells to the inducers can affect the development of somatic embryos, which is partly why different patterns of origination were observed for these embryos of the THB papaya cultivar. Embryos cultured in induction medium with high auxin concentrations develop predominantly indirectly; secondary embryos originate directly from the protoderm of the primary embryos cultured in induction medium or maturation medium.

The lack of embryogenic synchronization and the simultaneous occurrence of precocious and late-stage embryos have also been reported in other varieties of papaya (Fernando et al. 2001, Anandan et al. 2012) and in other species, like passionfruit (Silva et al. 2015). This process may be related to the secondary embryogenesis that occurred during the maturation stage in the absence of auxins; during this process, secondary embryos were formed on the surface of the embryonic axis near the radicle. 
The presence of connected embryos in the late and early stages indicates that secondary embryogenesis occurred in current study. Given the protodermal connection between torpedo-like and globular embryos in histological analysis, it is likely that secondary embryogenesis in this papaya cultivar can originate directly from the surface cells and that the formation of a callus is not necessary. Silva et al. (2009) similarly observed secondary embryogenesis in Passiflora cincinnata cultured in media without growth regulators; these authors reported that the intense production of secondary embryos on the surface negatively affected the germination of primary embryos. Secondary embryos also negatively affected the germination and conversion of primary embryos in this study (data not shown).

The occurrence of abnormalities during the embryogenic process is common (Fernando et al. 2002, Konieczny et al. 2012). It has been suggested that these abnormalities are associated with the culture duration and the use of high auxin concentrations (Pescador et al. 2008). Furthermore, synthetic auxins (especially 2,4-D) can disturb polar auxin transport processes that are required for the establishment of bilateral symmetry and the differentiation of cotyledons (Gaj 2004).

The results of this study indicate that a higher induction frequency of SEs was achieved with cotyledonary leaves cultured in medium containing 4-CPA $(25 \mu \mathrm{M})$ than with apical shoots and the auxin 2,4-D. The histological analysis of cotyledonary leaves shows that the embryogenic process begins in the parenchymal region with the proliferation of embryogenic masses to form somatic embryos via multicellular and indirect pathways. The addition of $\mathrm{ABA}(0.5 \mu \mathrm{M})$ and $\mathrm{AC}\left(15 \mathrm{~g} \mathrm{~L}^{-1}\right)$ to the medium resulted in elevated $\mathrm{SE}$ induction frequencies and reduced precocious germination rates. The successful conversion of somatic embryos into seedlings and the development of normal morphology are both directly related to the quality of the maturation process.

\section{ACKNOWLEDGMENTS}

The owner of the farm "Vovô Délio", Edivaldo Permanhane and his manager Waguinho for giving the seeds of the cultivar THB.

\section{REFERENCES}

ABOSHAMA HMS. 2011. Somatic embryogenesis proliferation, maturation and germination in Cajanus cajan. World J Agri Sci 7: 86-95.

ALKHATEEB AA. 2006. Somatic embryogenesis in date palm (Phoenix dactylifera L.) cv. Sukary in response to sucrose and polyethylene glycol. Biotech 5: 466-470.

AMAN N AND AFRASIAB H. 2014. Primary and secondary somatic embryogenesis from leaf explants of rosemary (Rosmarinus officinalis L. - Lamiaceae). Pak J Bot 46: 903-909.

ANANDAN R, SUDHAKARA D, BALASUBRAMANIANA P AND GUTIEIRREZ-MORAB A. 2012. In vitro somatic embryogenesis from suspension cultures of Carica papaya L. Sci Hortic-Amsterdam 136: 43-49.

ASCENCIO-CABRAL A, GUTIÉRREZ-PULIDO H, RODRÍGUEZ-GARAY B AND GUTIÉRREZ-MORA A. 2008. Plant regeneration of Carica papaya L. through somatic embryogenesis in response to light quality, gelling agent and phloridzin. Sci Hortic-Amsterdam 118: 155-160.

BELL LM, TRIGIANO RN AND CONGER BV. 1993. Relationship of abscisic acid to somatic embryogenesis in Dactylis glomerata. Enviro Expr Bot 33: 495-499.

CALIC D, DEVRNJA N, MILOJEVIC J, KOSTIC I, JANOSEVIC D, BUDIMIR S AND ZDRAVKOVICKORAC S. 2012. Abscisic acid effect on improving horse chestnut secondary somatic embryogenesis. HortScience 47: 1741-1744.

CALIC-DRAGOSAVAC D, ZDRAVKOVI-KORAC S, BOHANEC B, RADOJEVIC L, VINTERHALTER B, STEVOVIC S, CINGEL A AND SAVIC J. 2010. Effect of activated charcoal, abscisic acid and polyethylene glycol on maturation, germination and conversion of Aesculus hippocastanum androgenic embryos. Afr J Biotechnol 9: 3786-3793.

CAPELLE V ET AL. 2010. QTLs and candidate genes for desiccation and abscisic acid content in maize kernels. BMC Plant Biol 10: 1-22.

CAPELO AM, SILVA S, BRITO G AND SANTOS C. 2011. Somatic embryogenesis induction in leaves and petioles of a mature wild olive. Plant Cell Tiss Org 103: 237-242. 
CARLOS-HILARIO LR AND CHRISTOPHER DA. 2015. Improved Agrobacterium-mediated transformation of Carica papaya cultivar 'Kapoho' from embryogenic cell suspension cultures. In Vitro Cell Dev-P1 51: 580-587.

CASTILlO B, SMITH MAL AND YADAVA UL. 1998. Plant regeneration from encapsulated somatic embryos of Carica papaya L. Plant Cell Rep 17: 172-176.

CASTILLÓN J AND KAMO K. 2002. Maturation and conversion of somatic embryos of three genetically diverse rose cultivars. HortScience 37: 973-977.

CHINALIA FA, REGALI-SELEGHIN MH AND CORREA EM. 2007. 2,4-D toxicity: cause, effect and control. Terre Aqua Enviro Toxic 1: 24-33.

CRUZ CD. 2016. Genes Software - extended and integrated with the R, Matlab and Selegen. Acta Sci Agron 38: 547552.

DODEMAN VL, DUCREUX G AND KREIS M. 1997. Zygotic embryogenesis versus somatic embryogenesis. J Exp Bot 48: 1493-1509.

DURZAN DJ AND GUPTA PK. 1988. Somatic embryogenesis and polyembryogenesis in conifers. Downstream Processes. Adv Biotech Proc 9: 53-81.

FARZANA ARF, PALKADAPALA PGVN, MEDDEGODA KMMN, SAMARAJEEWA PK AND EESWARA JP. 2008. Somatic embryogenesis in papaya (Carica papaya L.) cv. Rathna. J Natl Sci Found Sri 36: 41-50.

FEHÉR A. 2005. Why somatic plant cells start to form embryos? In: Mujib A and Samaj J (Eds), Somatic embryogenesis. Berlin: Springer-Verlag, DEU, p. 85-101.

FEHÉR A. 2015. Somatic embryogenesis - Stress-induced remodeling of plant cell fate. BBA-Gene Regul Mech 1849: 385-402.

FERNANDO JA, MELO M, SOARES MKM AND APPEZZATO-DA-GLÓRIA B. 2001. Anatomy of somatic embryogenesis in Carica papaya L. Braz Arch Biol Techn 44: 247-255.

FERNANDO JA, VIEIRA MLC, GERALDI IO AND APPEZZATO-DA-GLÓRIA B. 2002. Anatomical study of somatic embryogenesis in Glycine max (L.) Merrill. Braz Arch Biol Techn 45: 277-286.

FILONOVA LH, BOZHKOV PV, BRUKHIN VB, DANIEL G, ZHIVOTOVSKY B AND VON ARNOLD S. 2000. Two waves of programmed cell death occur during formation and development of somatic embryos in the gymnosperm. J Cell Sci 113: 4399-4411.

FITCH MMM, MANSHARDT RM, GONSALVES D AND SLIGHTOM JL. 1993. Transgenic papaya plants from Agrobacterium-mediated transformation of somatic embryos. Plant Cell Rep 12: 245-249.

GAJ MD. 2004. Factors influencing somatic embryogenesis induction and regeneration with particular reference to Arabidopsis thaliana (L.) Heynh. Plant Growth Regul 43: 27-47.
GROSSMANN K. 2003. Mediation of herbicide effects by hormone interactions. J Plant Growth Regul 22: 109-122.

GROSSMANN K. 2007. Auxin herbicide action: lifting the veil step by step. Plant Sig Behavior 2: 421-423.

GUTMANN M, VON ADERKAS P, LABEL P AND LELU M-A. 1996. Effects of abscisic acid on somatic embryo maturation of hybrid larch. J Exp Bot 47: 1905-1917.

HERINGER AS, VALE EM, BARROSO T, SANTACATARINA C AND SILVEIRA V. 2013. Polyethylene glycol effects on somatic embryogenesis of papaya hybrid UENF/CALIMAN 01 seeds. Theor Exp Plant Physiol 25: 116-124.

HOMHUAN S, KIJWIJAN B, WANGSOMNUK P, BODHIPADMA K AND LEUNG DWM. 2008. Variation of plants derived from indirect somatic embryogenesis in cotyledon explants of papaya. J Sci Soc Thailand 34: $347-$ 352.

IIDA Y, WATABE K-I, KAMADA H AND HARADA H. 1992. Effects of abscisic acid on the induction of desiccation tolerance in carrot somatic embryos. J Plant Physiol 140: 356-360.

JIMÉNEZ VM. 2005. Involvement of plant hormones and plant growth regulators on in vitro somatic embryogenesis. Plant Growth Regul 47: 91-110.

KARNOVSKY MJ. 1965. A formaldehyde-glutaraldehyde fixative of high osmolality for use in electron microscopy. J Cell Biol 27: 137-138.

KINTZIOS S, MANOS C AND MAKRI O. 1999. Somatic embryogenesis from mature leaves of rose (Rosa sp.). Plant Cell Rep 18: 467-472.

KONIECZNY R, SLIWINSKA E, PILARSKA M AND TULEJA M. 2012. Morphohistological and flow cytometric analysis of somatic embryogenesis in Trifolium nigrescens Viv. Plant Cell Tiss Org 109: 131-141.

KURCZYNSKA EU, GAJ MD, UJCZAK A AND MAZUR E. 2007. Histological analysis of direct somatic embryogenesis in Arabidopsis thaliana (L.) Heynh. Planta 226: 619-628.

LEE KS, LEE JC AND SOH W-Y. 1998. Effects of ABA on secondary embryogenesis from somatic embryos induced from inflorescence culture of Aralia cordata Thunb. J Plant Biol 41: 187-192.

LOISEAU J, MARCHE C AND DEUNFF YL. 1995. Effects of auxins, cytokinins, carbohydrates and amino acids on somatic embryogenesis induction from shoot apices of pea. Plant Cell Tiss Org 41: 267-275.

LÓPEZ-PÉREZ AJ, CARREÑO J, MARTÍNEZ-CUTILLAS A AND DABAUZA M. 2005. High embryogenic ability and plant regeneration of table grapevine cultivars (Vitis vinifera L.) induced by activated charcoal. Vitis 44: 79-85. LOSCHIAVO F, PITTO L, COZZANI F VALLONE D AND TERZI M. 1991. Modulation of auxin binding proteins in cell suspensions proteins in cell suspensions: I. Differential 
responses of carrot embryo cultures. Plant Physiol 97: 6064.

MALABADI RB, KUMAR SV, MULGUND GS AND NATARAJA K. 2011. Induction of somatic embryogenesis in papaya (Carica papaya). Res Biotechn 2: 40-55.

MOURA EF AND MOTOIKE SY. 2009. Induction of somatic embryogenesis in immature seeds of guava tree cv. Paluma. Rev Bras Frutic 31: 507-511.

MUNHOZ M, LUZ CFP, MEISSNER-FILHO PE, BARTH OM AND REINERT F. 2008. Pollen viability of Carica papaya L.: a methodological comparison. Braz J Bot 31: 209-214.

MURASHIGE TM AND SKOOG F. 1962. A revised medium for rapid growth and bioassays with tobacco tissue cultures. Physiol Plantarum 15: 473-497.

O'BRIEN TP AND MCCULLY ME. 1981. The study of plant structure: principles and selected methods. Melbourne: Termarcarphi Pty. Ltd., AUS, 357 p.

OGATA Y, IIZUKA M, NAKAYAMA D, IKEDA M, KAMADA H AND KOSHIBA T. 2005. Possible involvement of abscisic acid in the induction of secondary somatic embryogenesis on seed-coat-derived carrot somatic embryos. Planta 221: 417-423.

PARVEEN S AND SHAHZAD A. 2014. Somatic embryogenesis and plantlet regeneration of Cassia angustifolia from immature cotyledon-derived callus. Biol Plantarum 58: 411-418.

PEREIRA PIP, HOCHER V, VERDEIL JL, BANDUPRIYA HDD, YAKANDAWALA DMD AND WEERAKOON LK. 2008. Androgenic potential in coconut (Cocos nucifera L.). Plant Cell Tiss Org 69: 167-176.

PÉREZ LP, MONTESINOS YP, OLMEDO JG, RODRIGUEZ RB, SÁNCHEZ RR, MONTENEGRO ON, ESCRIBA RCR, DANIELS D AND GÓMEZ-KOSKY R. 2016. Effect of phloroglucinol on rooting and in vitro acclimatization of papaya (Carica papaya L. var. Maradol Roja). In Vitro Cell Dev-P1 52: 196-203.

PESCADOR R, KERBAUY GB, VIVIANI D AND KRAUS JE. 2008. Anomalous somatic embryos in Acca sellowiana (O. Berg) Burret (Myrtaceae). Rev Bras Bot 31: 155-164.

PINTO DLP, ALMEIDA AMR, RÊGO MM, SILVA ML, OLIVEIRA EJ AND OTONI WC. 2011. Somatic embryogenesis from mature zygotic embryos of commercial passionfruit (Passiflora edulis Sims) genotypes. Plant Cell Tiss Org 107: 521-530.

PRAKASH MG AND GURUMURTHI K. 2009. Effects of type of explant and age, plant growth regulators and medium strength on somatic embryogenesis and plant regeneration in Eucalyptus camaldulensis. Plant Cell Tiss Org 100: 13.

RAGHAVAN C, ONG EK, DALLING MJ AND STEVENSON TW. 2005. Effect of herbicidal application of 2,4-dichlorophenoxyacetic acid in Arabidopsis. Funct Integr Genomic 5: 4-17.

RAGHAVAN C, ONG EK, DALLING MJAND STEVENSON TW. 2006. Regulation of genes associated with auxin, ethylene and ABA pathways by 2,4-dichlorophenoxyacetic acid in Arabidopsis. Funct Integr Genomic 6: 60-70.

RENUKDAS N, MOHAN ML, KHUSPE SS AND RAWAL SK. 2003. Influence of boron on somatic embryogenesis in papaya. Biol Plantarum 47: 129-132.

RENUKDAS N, MOHAN ML, KHUSPE SS AND RAWAL SK. 2006. Influence of phytohormones, culture conditions and ethylene antagonists on somatic embryo maturation and plant regeneration in papaya. Int J Agric Res 1: 151160.

ROCHA DI, VIEIRA LM, TANAKA FAO, SILVA LC AND OTONI WC. 2012. Somatic embryogenesis of a wild passion fruit species Passiflora cincinnata Masters: histocytological and histochemical evidences. Protoplasma 249: 747-758.

SAHA M, PHATAK A AND CHANDRA N. 2004. Somatic embryogenesis in different varieties of Carica papaya L. J Tiss Res 4: 143-145.

SCHMILDT O, CAMPOSTRINI E, SCHMILDT ER, TORRES-NETTO A, PEÇANHA AL, FERRAZ TM, FERREGUETTI GA, ALEXANDRE RS AND GONZÁLEZ JC. 2016. Effects of indol butyric acid concentration on propagation from cuttings of papaya cultivars 'Golden' and 'Uenf/Caliman 01'. Fruits 71: 27-33.

SHOLI NJY, CHAURASIA A, AGRAWAL A AND SARIN NB. 2009. ABA enhances plant regeneration of somatic embryos derived from cell suspension cultures of plantain cv. Spambia (Musa sp.). Plant Cell Tiss Org 99: 133-140.

SILVA GM, CRUZ ACF, OTONI WC, PEREIRA TNS, ROCHA DI AND SILVA ML. 2015. Histochemical evaluation of induction of somatic embryogenesis in Passiflora edulis Sims (Passifloraceae). In Vitro Cell DevP1 51: 539-545.

SILVA ML, PINTO DLP, GUERRA MP, FLOH EIS, BRUCKNER CH AND OTONI WC. 2009. A novel regeneration system for a wild passion fruit species (Passiflora cincinnata Mast.) based on somatic embryogenesis from mature zygotic embryos. Plant Cell Tiss Org 99: 47-54.

STEINER N, VIEIRA FN, MALDONADO S AND GUERRA MP. 2005. Effect of carbon source on morphology and histodifferention of Araucaria angustifolia embryogenic cultures. Braz Arch Biol Techn 48: 895-903.

STUART DAAND MCCALL CM. 1992. Induction of somatic embryogenesis using side chain and ring modified forms of phenoxy acid growth regulators. Plant Physiol 99: 111118.

SUGAYA S, OHMIYA A, KUKUCHI M AND HAYASHI T. 2000. Isolation and characterization of a $60 \mathrm{kDa}$ 
2,4-D-binding protein from the shoot apices of peach trees (Prunus persica L.): It is a homologue of protein disulfide isomerase. Plant Cell Physiol 41: 503-508.

VALE EM, HERINGER AS, BARROSO T, FERREIRA ATS, COSTA MN, PERALES JEA, SANTA-CATARINA C, SILVEIRA V AND FERREIRA ATS. 2014. Comparative proteomic analysis of somatic embryo maturation in Carica papaya L. Proteome Sci 12: 2-17.

VON ARNOLD S, SABALA I, BOZHKOV P, DYACHOK J AND FILONOVA L. 2002. Developmental pathways of somatic embryogenesis. Plant Cell Tiss Org 69: 233-249.

VOOKOVÁ B AND KORMUTÁK A. 2002. Some features of somatic embryo maturation of algerian fir. In Vitro Cell Dev-P1 38: 549-551.
WALSH TA, NEAL R, MERLO AO, HONMA M, HICKS GR, WOLFF K, MATSUMURA W AND DAVIES JP. 2006. Mutations in an auxin receptor homolog AFB5 and in SGT1b confer resistance to synthetic picolinate auxins and not to 2,4-dichlorophenoxyacetic acid or indole-3acetic acid in Arabidopsis. Plant Physiol 142: 542-552.

YU TA, YEH SD AND YANG JS. 2003. Comparison of the effects of kanamycin and geneticin on regeneration of papaya from root tissue. Plant Cell Tiss Org 74: 169-178.

ZAVATTIERI MA, FREDERICO AM, LIMA M, SABINO R AND ARNHOLDT-SCHMITT B. 2010. Induction of somatic embryogenesis as an example of stress-related plant reactions. Electron J Biotechno 13: 1-9. 